\title{
DOES VOLATILITY OF TRADE RECEIVABLES AFFECT CORPORATE CASH HOLDINGS? EMPIRICAL EVIDENCE FROM TURKEY
}

\author{
DOI: $10.17261 /$ Pressacademia.2019.1152 \\ JEFA- V.6-ISS.4-2019(4)-p.217-229
}

\section{Guldehen Adiguzel}

Boğaziçi University, Management Department, Bebek, 34342 Beşiktaş, Istanbul, Turkey guldehen.adiguzel@gmail.com, ORCID: 0000-0003-1326-0648

To cite this document

Adiguzel, G. (2019). Does volatility of trade receivables affect corporate cash holdings? Empirical evidence from Turkey. Journal of Economics, Finance and Accounting (JEFA), V.6(4), p.217-229.

Permanent link to this document: http://doi.org/10.17261/Pressacademia.2019.1152

Copyright: Published by PressAcademia and limited licenced re-use rights only.

\begin{abstract}
Purpose - This study aims to analyze the direct impact of trade receivables volatility on corporate cash holdings. Unlike previous studies, the present paper focuses on variability of a firm's investment in trade credit which proxies instability of a firm's trade receivables policy.

Methodology - The sample is composed of 330 Turkish industrials listed on Borsa Istanbul from 2000 to 2017. The model is estimated via system GMM (Generalized Method of Moments) to account for the partial adjustment process towards the target cash level and also to address the potential endogeneity issue related with volatility of trade receivables.

Findings- Estimations establish a significant negative effect of trade receivables volatility on cash holdings. The results are robust to alternative definitions of cash holdings and trade receivables volatility.

Conclusion - The evidence presented in this study suggests that instability of trade receivables policy weakens liquidity position of firms.
\end{abstract}

Keywords: Trade credit, corporate cash, Borsa Istanbul

JEL Codes: G30, G11

\section{INTRODUCTION}

Majority of non-financial companies across the world are exposed to credit risk due to provision of trade credit to their customers. Trade receivables comprise a significant portion of firms' assets. The average share of trade receivables in total assets is $17 \%$ for publicly listed companies (El Ghoul \& Zheng, 2016) and is between $19 \%$ and $39 \%$ across small and medium sized companies (Garcia-Teruel \& Martinez-Solano, 2010). Theories of trade credit provision refer to information asymmetries in capital and product markets as the main drivers of firms' motivation for offering trade credit to their customers. Determinants of trade credit provision is a relatively well-researched area whereas consequences of trade credit provision still remains an under-researched area in trade credit literature. More specifically, existing literature focuses on the impact of trade credit provision on corporate profitability, firm value, stock returns, and growth (Deloof, 2003; Garcia-Teruel \& Martinez-Solano, 2007, Gill, Biger, \& Mathur, 2010; Hill, Kelly, \& Lockhart, 2012; Hill, Kelly, \& Venkiteshwaran, 2015; Box, Davis, Hill, \& Lawrey, 2018).

Such extensive provision of trade credit necessitates rigorous analysis of its effects at firm level. Analysis regarding the consequences of trade credit provision has been limited to use of level of trade receivables as the main explanatory variable of interest in the related literature (Deloof, 2003; Garcia-Teruel and Martinez-Solano, 2007; Hill, et al., 2012; Ferrando and Mulier, 2013; Hill, et al, 2015; Yazdanfar and Ohman, 2015; Box, et al., 2018). However, variability of a firm's investment in trade receivables, should also be factored into models analyzing effects of trade credit provision as this may well have a direct impact on financial position and performance of firms. Turkish listed firms invest one fourth of their assets in trade receivables. Moreover, they hold relatively low levels of cash compared to firms operating in other emerging countries (Fernandes \& Gonenc, 2016). Unfavorable consequences of instability in trade receivables policy may push cash holdings of 
Turkish firms down and may weaken their liquidity position Therefore, the analysis of the effect of a firm's investment in trade receivables on corporate cash holdings is even more critical for Turkish listed firms. By focusing on variability of trade receivables provision as the key explanatory variable of interest and by analyzing its direct impact on corporate cash holdings, the present study fills a gap in both trade credit and cash holdings literatures.

Firms that have a relatively stable trade receivables policy has a more stable mean ratio of trade receivables to total assets. Therefore, trade receivables investment policy of such firms are consistent and stable. On the contrary, some firms may have higher volatility of investment in trade receivables due to factors such as adoption of aggressive trade receivables policies and implementation of sales pull-in strategy. Higher trade receivables volatility may also imply weaknesses and instability regarding credit selection criteria, credit terms and credit monitoring process. Firms that increase their investment in trade receivables by offering credit to less creditworthy customers may experience higher write-offs due to increased delinquencies and higher portion of doubtful receivables becoming uncollectible over the medium term. Furthermore, sudden and more frequent shocks to the collection process makes cash management harder to deal with and persistence of these shocks may force management to take corrective action by tightening its trade receivables policy. Thus, another sudden change in trade receivables, this time in the opposite direction, creates even further volatility. Therefore, we hypothise that trade receivables volatility has negative impact on cash holdings. Thus, the present study brings a different perspective to our knowledge about the consequences of trade credit in the sense that rather than focusing on the level of investment in trade receivables, we study volatility of trade receivables and analyze its direct impact on cash holdings.

Based on a sample of 330 Turkish listed industrials across 2000 to 2017 period, we find that firms held about $8.8 \%$ of their assets in the form of cash and cash equivalents and invested about one fourth of their assets in trade receivables. Moreover, Turkish listed industrials with low trade receivables volatility (RECVOL) have consistently held higher cash compared to those with high RECVOL within the sample period except for the pre-crisis and crisis periods (2007 and 2008). Additionally, such firms have consistently invested a lower portion of their assets in trade receivables compared to firms with high RECVOL. Finally, investment in trade receivables by firms with low RECVOL has been quite stable, whereas firms with high RECVOL increased the share of investment in trade receivables from $26 \%$ in 2003 to $31 \%$ in 2017.

The direct impact of trade receivables volatility on cash holdings is tested via system GMM (Generalized Method of Moments), which is appropriate for dynamic models. Additionally, by employing system GMM, we also address the potential endogeneity issue related with cash holdings and trade receivables volatility, which may result from omitted variables bias. Thus, in all estimations, trade receivables volatility is treated as an endogenous rather than a strictly exogeneous variable.

The empirical findings suggest that firms with relatively higher volatility of investment in trade receivables tend to hold less cash than firms with relatively lower trade receivables volatility. This finding supports our hypothesis and suggests that the increased frequency of unexpected schocks to the collection process, resulting from aggressive trade receivables policies, makes cash management difficult to conduct and that companies with high volatility of investment in trade receivables end up with lower cash holdings. Therefore, high volatility in trade receivables hampers the ability of companies to take proactive action to prevent cash levels from getting reduced or limits the effectiveness of such proactive action. We also check the robustness of the results by utilizing alternative definitions of the dependent variable and trade receivables volatility and document that our model is robust to these alternative definitions and thus our conclusion remains the same.

This constitutes valuable new evidence on the consequences of trade receivables on three fronts. First, no study to date, except that conducted by $\mathrm{Wu}$, Rui \& Wu (2012), has provided evidence on the cash holdings consequences of trade credit provision. Therefore, this is the second study to document the direct impact of investment in trade receivables on cash holdings in an emerging market. Second, trade credit literature has not studied the consequences of trade receivables volatility at all. Existing studies used level of trade receivables as the key variable of interest. This is the first study that approaches trade receivables provision differently, utilizes volatility of investment in trade receivables as the key variable of interest and investigates the cash holdings consequences of such policy. Third, this study extends the findings of Uyar \& Kuzey (2014) by providing further evidence on the determinants of cash holdings for Turkish listed industrials.

The remainder of the paper is organized as follows. Section 2 provides a summary of literature on trade credit and cash holdings and also develops the testable hypothesis. Section 3 describes the data and sample selection, provides variable definitions and presents the regression model and estimation methodology. Empirical results and robustness checks are presented in Section 4. Section 5 concludes the study. 


\section{LITERATURE REVIEW}

\subsection{Trade Credit Literature}

Earliest trade credit research found that firms with relatively stronger liquidity increase the supply of trade credit to relatively smaller and less liquid firms when monetary policy is tightened (Meltzer, 1960; Brechling \& Lipsey,1963). Later, researchers started to focus on theoretical models that would explain the major motivations, which lie at the heart of suppliers' willingness to extend trade credit. It is commonly agreed that firms offer trade credit to achieve competitive advantage due to imperfections in financial markets and product markets as well as lack of perfect substitutes for all commodities, and existence of transaction costs or information costs. Major motives for trade credit supply is grouped under five main categories, which are: financing motive, efficiency motive, price discrimination motive, investment motive and quality assurance motive. A review of trade credit theories can be found in Wilson \& Summers (2002) and Cheng \& Pike (2003).

Empirical research regarding trade credit provision falls under two main categories. One stream focuses on the determinants of trade credit supply and the other stream focuses on the consequences of trade credit supply. Studies that explore the determinants of trade credit supply and that test trade credit theories fall under the first category (Mian \& Smith, 1992; Deloof \& Jegers, 1996; Petersen \& Rajan, 1997; Long, Malitz, \& Ravid, 1993; Love, Preve, \& Sarria-Allende, 2007; Harris, 2015). Furthermore, non-financial factors, such as the quality of the good (differentiated versus standard), industry competition and bargaining power of firms (Burkart \& Ellingsen, 2004; Dass, Kale, \& Nanda, 2015) are found to be influential on the level of trade credit provided to customers. All of these suggest that trade credit provision can be justified not by a single theory, but by a set of multiple motivations. The second stream of empirical research in trade credit provision focuses on consequences of trade credit. This is a relatively under-researched area and this study mainly contributes to this area of research. Previous research in this area focus on several consequences of trade credit provision such as profitability, growth, stock return and firm value (Deloof, 2003; Garcia-Teruel \& Martinez-Solano, 2007; Gill et al., 2010; Hill, et al., 2012; Hill, et al., 2015; Box, et al., 2018; Ferrando and Mulier, 2013; Yazdanfar and Ohman, 2015).

\subsection{Cash Holdings Literature}

The rationale for firms to hold cash is justified by three alternative theories, which are trade-off theory, pecking order theory and free cash flow theory. As per the trade-off theory, there is an optimal level of cash holdings that is determined by trading off the marginal benefits of holdings liquid assets against the marginal cost of investing in liquid assets (Miller \& Orr, 1966; Kim, Mauer, \& Sherman, 1998). It is argued that due to imperfections in capital markets, firms should hold cash at the optimal level, otherwise firm value would be impaired. Alternatively, pecking order theory proposes that firms hold cash in order to be able to finance future investment opportunities as and when they appear (Myers, 1984; Myers \& Majluf, 1984). As per this theory, firms accumulate cash to ensure that internal funds are sufficiently available when investment opportunities arise and thus costly external financing is avoided. Finally, free-cash flow theory proposes that agency problems are major determinants of cash holdings (Jensen \& Meckling, 1976) in the sense that the level of corporate cash holdings reflects the managers' tendency to accumulate cash in an effort to avoid the discipline of capital markets.

Empirical literature on the determinants of cash holdings is massive (Opler, Pinkowitz, Stulz, \& Williamson, 1999; Bates, Kahle, \& Stulz, 2009; Graham \& Leary, 2018; Gao, Harford, \& Li, 2013; Ozkan \& Ozkan, 2004; Guney, Ozkan, \& Ozkan, 2007; Pinkowitz, Stulz, \& Williamson, 2003; Dittmar \& Mahrt-Smith, 2007; Harford, Mansi, \& Maxwell, 2008). Additionaly, an increasing number of studies have focused on non-financial determinants of corporate cash holdings. Examples of such factors are product market dynamics, organizational structure of the firm, nature of supplier-buyer relationships, family control, level of multinationality and dependence on skilled labor (Subramaniam, Tang, Yue, \& Zhou, 2011; Itzkowitz, 2013; Duran, Lozano, \& Yaman, 2016; Fernandes \& Gonenc, 2016; Haushalter, Klasa, \& Maxwell, 2007; Ghaly, Dang, \& Stathopoulos, 2017). Wu et al.'s (2012) paper remains the only study that addresses cash holdings consequences of trade credit provision.

\subsection{Hypothesis Development}

A major shortcoming of the existing literature is that no study to date has researched the consequences of instability in trade receivables policy. If a company has a stable trade receivables policy, share of trade receivables in total assets does not vary much from one year to the other and shows limited variation around a relatively stable mean value. Similarly, if the increase in the level of investment in trade receivables from one year to the other is gradual, the share of trade receivables in total assets may go up slowly and steadily and the variation would be under control. On the contrary, weaknesses in trade receivables policy may create instability in trade credit offered to customers. Such weaknesses may arise from changes in credit selection criteria and/or credit terms as well as deficiencies in credit monitoring process (Gitman \& Zutter, 2015). If the firm does not maintain a robust credit selection policy, it may end up extending credit to ineligible customers. Similarly, if the 
firm does not offer proper credit terms to its clients, it may start facing difficulties in collecting due amounts from its customers on time. Moreover, weaknesses in credit monitoring process may lead to a situation where collection issues are left unnoticed. In such cases, the company may have to incur excessive credit losses. For instance, if the firm is very aggressive in its trade receivables policy, management may take action to penetrate the market quickly by offering longer terms to less creditworthy client-segment (Petersen \& Rajan, 1994; Biais \& Gollier, 1997). Alternatively, in an effort to meet aggressive revenue targets, some firms may choose to adopt sales pull-in strategy to attract less creditworthy customers (Melumad \& Nissim, 2009). Buyers that accept longer payment terms are less creditworthy (Petersen \& Rajan, 1997; Paul, 2004). Thus, loosening of credit terms aggressively may lead to a deterioration of credit quality on the supplier front. Although trade credit provision has been a tool to manage growth (Ferrando \& Mulier, 2013; Yazdanfar \& Ohman, 2015), the sustainability of an aggressive trade receivables strategy is highly questionable. Too much investment in trade credit has negative consequences on firm profitability (Deloof, 2003; Garcia-Teruel \& Martinez-Solano, 2007; Gill et al., 2010). Aggressive trade receivables strategies may seem reasonable in the short term. However, no matter how well-functioning the credit department may be, higher write-offs are unavoidable over the medium term. Sudden and more frequent shocks to the collection process resulting from increased number of defaulting customers would create high volatility in trade receivables. Persistence of these shocks may force management to take corrective action by tightening its trade receivables policy, which would trigger a sharp drop in the share of trade receivables in total assets. Such action would result in increased volatility of trade receivables investment. Ultimately, cash management becomes very difficult to administer. As collections from customers are the lifeblood of companies, increased unpredictability surrounding the collection process hampers the ability of management to keep corporate cash levels unaffected. This discussion leads to the following hypothesis:

Hypothesis H1: Trade receivables volatility has negative impact on corporate cash holdings.

\section{RESEARCH DESIGN}

\subsection{Data and Sample}

The sample is composed of publicly traded Turkish industrial firms listed on Borsa Istanbul from 2000 to 2017. The initial sample is the set of all firms for which data are available on the Thompson Reuters Datastream database. The final sample includes 330 firms, both surviving and non-surviving, that appear on Datastream at any time in the sample period. Therefore, survivorship bias is limited. The aggregate sample has 5,940 firm-year observations. As some measures used in the regressions are not fully available for all firms and as some variables are based on the standard deviations over a 4-year period (from $t$ to $\mathrm{t}-3$ ), the sample size used in the regression analyses is smaller. All continous variables are winsorized at the 1 percent and 99 percent levels to minimize the influence of outliers.

\subsection{Variables}

Dependent variable is CASH1, which is computed as natural logarithm of cash and marketable securities scaled by total assets. This definition of cash holdings is in line with several previous studies such as Kim, Mauer and Sherman (1998), Bates et al (2009), Gao et al. (2013). To ensure robustness of the results, we also use an alternative measure of cash holdings (CASH2), which is defined as natural logarithm of cash and marketable securities scaled by net assets (total assets minus cash and marketable securities).

The key explanatory variable of interest is the volatility of a firm's investment in trade receivables (RECVOL). We first calculate the share of trade receivables in total assets for each firm (REC) across all years. Then we compute the standard deviation of $R E C$ across a four-year period from $t$ to $t-3$. If any of the REC value is missing within the computation period, RECVOL is not calculated and is treated as missing. As the calculation of RECVOL requires 4 years of data, the initial observation is in 2003. Thus, regressions using RECVOL are run for 2003-2017 period.

Consistent with the majority of previous studies in cash holdings literature (Opler et al., 1999; Bates et al., 2009), the following variables are included in the baseline model specification to control for firm-specific determinants of cash holdings: GROWTH (asset growth rate from t-1 to t), SIZE (natural logarithm of total assets), LEVERAGE (total debt divided by total capital), CFO (cash flow from operations scaled by total assets), NWCAP (net working capital, which is current assets minus current liabilities minus cash and marketable securities, scaled by total assets), PPE (plant, property and equipment divided by total assets), CAPEX (capital expenditures scaled by total assets), DIV (dummy variable that takes a value of "1" in years in which the firm paid a cash dividend or " 0 " otherwise) and CFOVOL (operating cash flow variability computed as standard deviation of operating cash flow from $t-3$ to $t$ divided by average total assets net of cash and marketable securities over the same period). CFOVOL definition is in line with Guney, Ozkan and Ozkan (2007). Finally, the first lag of CASH1 is included as an explanatory variable due to the dynamic nature of the model, which is discussed in the next section. 


\subsection{Regression Model}

To examine whether the level of cash holdings is related to volatility of a firm's investment in trade receivables, we estimate the following baseline regression model:

$\mathrm{CASH}_{\mathrm{i}, \mathrm{t}}=\beta_{0}+\beta_{1} \mathrm{CASH}_{\mathrm{i}, \mathrm{t}-1}+\beta_{2}$ RECVOL $_{\mathrm{i}, \mathrm{t}}+\beta_{3}$ CONTROLS $_{\mathrm{i}, \mathrm{t}}+$ Year Dummies $+\varepsilon_{\mathrm{i}, \mathrm{t}}$

In line with several studies in the literature (Ozkan \& Ozkan, 2004; Garcia-Teruel \& Martinez-Solano, 2008), we employ a dynamic model that incorporates a gradual adjustment process towards the target cash holdings level. Therefore, one lag of the dependent variable $\left(\mathrm{CASH}_{\mathrm{i}, \mathrm{t}-1}\right)$, which captures the speed of convergence of cash to its target level, is included in the baseline model specification. RECVOL is the key variable of interest. CONTROLS represent the set of control variables as explained above. Year dummies are also included in the model to control for economic factors that may affect corporate cash holdings. $\varepsilon_{i, t}$ is the error term. " $\mathrm{i}$ " and " $\mathrm{t}$ " are indicators of firm and year, respectively.

As suggested by Blundell \& Bond (1998) and Brown \& Petersen (2011), the dynamic panel data cash holdings model is estimated via system GMM. There are mainly two reasons for the choice of system GMM as the estimation strategy in this study. First, system GMM is appropriate for models where lagged value(s) of the dependent variable are included in the model specification as independent variables. Second, by employing system GMM, we address the potential endogeneity issue related with CASH and RECVOL, which may result from a possible correlation between RECVOL and unobserved factors (both permanent and time-varying) affecting cash holdings, which are captured by the error term. If left unaddressed, these unobserved factors, such as corporate governance, corporate culture and diversification, may lead to biased estimators, which is referred to as omitted variables bias. System GMM is executed by use of Roodman's (2009) 'xtabond2' module in Stata.

Several previous studies have documented the impact of non-financial factors on cash holdings (Dittmar \& Mahrt-Smith, 2007; Haushalter et al., 2007; Harford, et al., 2008; Subramaniam et al., 2011; Itzkowitz, 2013 and Fernandes \& Gonenc, 2016). These non-financial factors may well have an impact on RECVOL. For instance, management in firms that are not wellgoverned may be more inclined to adapt varying trade receivables strategies to meet short-term objectives and thus create higher trade receivables volatility. Additionally, if the firm is operating in a market with relatively higher risk of market share loss, such a firm may be expected to have a more volatile trade receivables policy, which may be subject to frequent changes in an effort to retain and gain market share. Furthermore, compared to focused firms, diversified firms may have higher RECVOL due to several risks they are exposed to and higher probability of unexpected shocks to trade receivables. Moreover, CEO attributes may also impact RECVOL. Firms with optimistic CEOs, who estimate a lower-than-normal probability of default for customers with low creditworthiness, may adopt a more liberal trade receivables policy. This may create volatility in trade receivables policy. Similarly, some CEOs may choose to invest part of their assets in relatively higher-risk customer segments by extending payment terms and take on excessive credit risk. Such firms may be exposed to higher volatility of trade receivables. Therefore, to avoid omitted variables bias, this study controls for the potential endogeneity of RECVOL by treating it as an endogenous variable, rather than strictly exogenous, and including the lagged value of RECVOL in the model as instruments.

Model specification is assessed by employing two tests. First, we report the second-order Arellano-Bond tests for serial correlation in the error term (Arellano \& Bond, 1991). The null hypothesis of this test is "no second-order serial correlation in the errors of the first-difference estimation equation". Additionally, we report the Hansen test results for the validity of the instruments (Hansen, 1982). If the model is correctly specified, instruments should be uncorrelated with the error term. The null hypothesis of Hansen test is "not a correlation between over-identifying instruments and the errors". Standard errors are robust to heteroscedasticity in all estimations.

\section{EMPIRICAL RESULTS AND DISCUSSIONS}

\subsection{Descriptive Statistics}

We initially examine the trends in cash holdings and trade receivables of firms. Average cash ratio has been down from $10.1 \%$ in 2000 to $7.7 \%$ in 2007. Its trend reversed in 2008 and reached 9.2\% in 2010. In 2015, an average firm held 9.9\% of its assets in cash and marketable securities. There was a sharp decrease in 2016 to $8 \%$. Average cash ratio of listed Turkish industrials is below those of firms operating in developed (19\%) and in emerging (12\%) markets (Fernandes \& Gonenc, 2016). As for the average trade receivables ratio, an average listed Turkish industrial firm invested $29.2 \%$ of its assets in trade receivables in 2000. This ratio started coming down in the following four years and reached $22.6 \%$ by 2004 . From 2005 to 2017 , it varied within a range of $22.6 \%$ and $25.5 \%$. Therefore, listed Turkish industrials invested about one fourth of their assets in trade 
receivables. Although this is below most of the Euro area countries' average trade receivables ratio (Ferrando \& Mullier, 2013), it is higher than US average of $13.7 \%$ (Chen \& Kieschnick, 2018).

Descriptive statistics for the main variables are presented in Table 1. The non-logarithmic ratios for CASH1 and CASH2 are $8.8 \%$ and $11.4 \%$, respectively. Summary statistics for the remaining variables indicate that an average listed Turkish industrial firm has grown by about $19.7 \%$ and has had an asset size of about 845 million TL. Total debt correponds to about one third of total capital for an average firm. Additionally, firms in the sample generate operating cash flow that correponds to about $4 \%$ of total assets. Net working capital comprises $5.8 \%$ of total assets on average. In terms of asset tangibility, mean PPE is $33 \%$. Moreover, CFOVOL and RECVOL means are $8.7 \%$ and $4.6 \%$, respectively. Finally, mean CAPEX ratio is $5 \%$ and $35 \%$ of observations in the sample represents instances of dividend pay-out.

Table 1: Descriptive Statistics

\begin{tabular}{lcccccc}
\hline Variables & $\mathbf{N}$ & Mean & Median & $\begin{array}{c}\text { Standard } \\
\text { Deviation }\end{array}$ & Minimum & Maximum \\
\hline CASH1 & 4092 & -3.346 & -2.994 & 1.664 & -8.861 & -0.599 \\
\hline CASH2 & 4092 & -3.247 & -2.943 & 1.758 & -8.861 & 0.196 \\
\hline GROWTH & 3756 & 0.197 & 0.128 & 0.313 & -0.396 & 2.102 \\
\hline SIZE & 4101 & 12.217 & 12.182 & 1.652 & 8.677 & 16.898 \\
\hline LEVERAGE & 3957 & 31.926 & 27.780 & 30.448 & -83.370 & 256.440 \\
\hline CFO & 3467 & 0.039 & 0.038 & 0.118 & -0.378 & 0.452 \\
\hline NWCAP & 4071 & 0.058 & 0.060 & 0.221 & -1.183 & 0.611 \\
\hline PPE & 4086 & 0.328 & 0.317 & 0.204 & 0.000 & 0.945 \\
\hline CFOVOL & 2473 & 0.087 & 0.064 & 0.074 & 0.008 & 0.484 \\
\hline CAPEX & 4005 & 0.049 & 0.031 & 0.055 & 0.000 & 0.354 \\
\hline DIV & 4106 & 0.352 & 0 & 0.478 & 0 & 1 \\
\hline RECVOL & 3088 & 0.046 & 0.034 & 0.038 & 0.002 & 0.228 \\
\hline NOte: This & prof & 5105 &
\end{tabular}

Note: This table presents the summary statistics for the variables. The definitions of the variables are as
presented in Section 3.2 .

Nrxt, we analyze univariate comparisons of firm characteristics (variable means) across low and high RECVOL sub-groups. Firms with RECVOL below/above the median RECVOL values (calculated separately for each year) are categorized as low/high RECVOL. The t-statistics and the corresponding $p$-values demonstrate that low and high RECVOL sub-groups are significantly different at the $0.1 \%$ level for all financial characteristics considered (CASH, GROWTH, SIZE, CFO, NWCAP, PPE CFOVOL, CAPEX and DIV) except LEVERAGE. Firms with low RECVOL have higher cash holdings, are bigger and have higher operating cash flow generation capability than the other group. Furthermore, firms with high RECVOL grow at a higher rate, invest a significantly higher portion of their assets in net working capital and have lower asset tangibility and higher CAPEX requirements than the other group. The occurance of dividend payments is more frequent among companies with low RECVOL. Average collection period of low RECVOL firms is about 3 months, whereas average collection period of high RECVOL firms is slightly above 5 months. All t-tests invoke the assumption of unequal variances and Satterthwaite's approximation formula.

The correlation analysis of the variables is reported in Table 2. The table shows that, except for the correlation between NWCAP and LEVERAGE, the correlations between the variables are not very high. Additionally, Variance Inflation Factor (VIF) values, which are reported in the last column of Table 2, are below widely accepted critical VIF value of 5 and thus verify the absence of multicollinearity among the independent variables.

Table 2: Pearson Correlation Matrix for the Variables

\begin{tabular}{|c|c|c|c|c|c|c|c|c|c|c|c|c|}
\hline Variables & CASH & GROWTH & SIZE & LEVERAGE & CFO & NWCAP & PPE & CFOVOL & CAPEX & DIV & RECVOL & VIF \\
\hline CASH & 1.0000 & & & & & & & & & & & \\
\hline GROWTH & $0.0806 * * *$ & 1.0000 & & & & & & & & & & 1.16 \\
\hline SIZE & $0.2832^{* * *}$ & 0.0044 & 1.0000 & & & & & & & & & 1.51 \\
\hline LEVERAGE & $-0.2350^{* * *}$ & -0.0171 & 0.0070 & 1.0000 & & & & & & & & 1.45 \\
\hline CFO & $0.2576^{* * *}$ & $-0.0458^{* * *}$ & $0.1880^{* * *}$ & $-0.2558^{* * *}$ & 1.0000 & & & & & & & 1.28 \\
\hline NWCAP & $0.1054^{* * *}$ & -0.0096 & $-0.1071^{* * *}$ & $-0.4467^{* * *}$ & -0.0052 & 1.0000 & & & & & & 1.55 \\
\hline
\end{tabular}




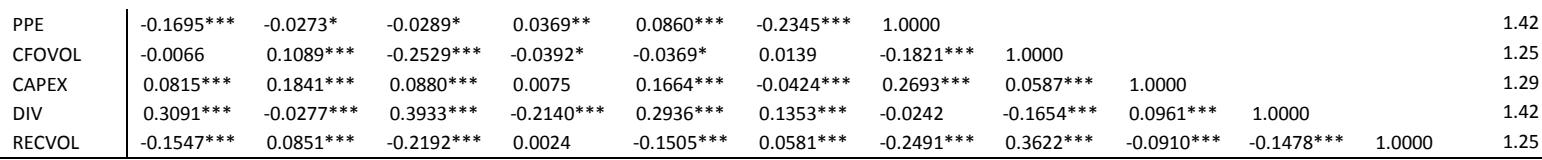

Note: This table reports the Pearson correlation matrix and VIF for the variables. $*, * *, * * *$ denote statistical significance at $10 \%, 5 \%$ and $1 \%$ levels, respectively. VIF is an index that shows how much the variance of an estimated regression coefficient is increased due to multicollinearity. Variable definitions are provided in Section 3.2.

\subsection{Baseline Results}

Estimation results of the baseline model are reported in Table 3. The baseline model is specified as follows:

$\mathrm{CASH}_{i, t}=\beta_{0}+\beta_{1} \mathrm{CASH}_{\mathrm{i}, \mathrm{t}-1}+\beta$ CONTROLS $_{\mathrm{i}, \mathrm{t}}+$ Year Dummies $+\varepsilon_{\mathrm{i}, \mathrm{t}}$

CONTROLS in the baseline model include GROWTH, SIZE, LEVERAGE, CFO, NWCAP, PPE, CFOVOL, CAPEX and DIV, as disCussed earlier. Table 3 shows the results of the estimation using two different proxies for cash holdings. In the first and second columns, dependent variable is $\mathrm{CASH} 1$ and $\mathrm{CASH} 2$, respectively. Year dummies are also included in the regressions although the results are not reported for brevity.

As per the baseline results presented in Table 3, the coefficients of $\mathrm{CASH}_{\mathrm{t}-1}$ are significant at $1 \%$ level and are positive. This confirms the partial adjustment process through the target cash level, which is consistent with the results reported by Guney et al. (2003) and Ozkan \& Ozkan (2004). GROWTH and CFO coefficients are positive and significant at $1 \%$ level in both models. These findings verify that firms with valuable growth opportunities hold more cash and also reflect firms' preference for internal over external finance. LEVERAGE, NWCAP and PPE coefficients are negative and statistically significant at $1 \%$ level in both models. This provides support for the prediction that when investments exceed retained earnings, debt grows and cash holdings fall. It also confirms that cash and net working capital are substitutes of each other and that fixed assets are alternative sources of liquidity. CAPEX coefficient is negative and statistically significant at $5 \%$ level, supporting the increased debt capacity of firms as a result of more CAPEX. These findings are in line with several previous studies in the related literature (Opler et al, 1999; Bates et al, 2009; Dass et al., 2015; Uyar \& Kuzey, 2014; Doring, Drobetz, Janzen, \& Meier, 2018). DIV coefficient is positive and significant at $5 \%$ level in both models. This finding supports the rationale that dividend-paying firms hold more cash than non-dividend-paying firms to avoid a situation in which they are short of cash to support their dividend payments (Loncan, 2019). CFOVOL coefficient is positive and in line with the existing literature that predict firms to hold more cash for precautionary purposes in case of high volatility of cash flow. However, p-value of CFOVOL indicates that it is not statistically significant in both models.

SIZE coefficient is positive and significant at $1 \%$ level. This finding is in line with studies supporting precautionary motive for holding cash, which asserts that cash is beneficial for firms due to avoidance of external finance costs when investment opportunities unexpectedly exceed internal resources (Kalcheva \& Lins, 2007; Itzkowitz, 2013; Hanlon, Maydew, \& Saavedra, 2017). According to the precautionary motive, firms hold more cash if they believe access to future financing is either costly or difficult to obtain. Therefore, the positive impact of SIZE on CASH may be due to the strength of precautionary motive for holding cash. Capital markets are relatively under-developed in Turkey. Moreover, there is lack of sufficient investor protection, lack of corporate transparency and lack of societal trust (McLean \& Zhao, 2018; Kalcheva \& Lins, 2007; Dudley \& Zhang, 2016). These factors put limitations on availability of external finance and this may be the reason of the strenght of precautionary motive for Turkish industrials.

Table 3: Estimation Results (Baseline Model)

\begin{tabular}{|c|c|c|c|c|}
\hline \multirow{2}{*}{ Variable } & \multicolumn{2}{|c|}{$\begin{array}{c}\text { Model } 1 \\
\text { Dependent Variable: CASH1 }\end{array}$} & \multicolumn{2}{|c|}{$\begin{array}{c}\text { Model } 2 \\
\text { Dependent Variable: CASH2 }\end{array}$} \\
\hline & Coefficient & p-value & Coefficient & $p$-value \\
\hline $\mathrm{CASH}_{\mathrm{t}-1}$ & $0.3974 * * *$ & 0.0000 & $0.4142 * * *$ & 0.0000 \\
\hline GROWTH & $0.7762^{* * *}$ & 0.0000 & $0.8590 * * *$ & 0.0000 \\
\hline SIZE & $0.1173 * * *$ & 0.0000 & $0.1194 * * *$ & 0.0000 \\
\hline LEVERAGE & $-0.0061 * * *$ & 0.0002 & $-0.0065 * * *$ & 0.0002 \\
\hline
\end{tabular}




\begin{tabular}{|c|c|c|c|c|}
\hline CFO & $2.6569 * * *$ & 0.0000 & $2.9335^{* * *}$ & 0.0000 \\
\hline NWCAP & $-0.6043 * * *$ & 0.0076 & $-0.6969 * * *$ & 0.0032 \\
\hline PPE & $-1.2085^{* * *}$ & 0.0000 & $-1.2918^{* * *}$ & 0.0000 \\
\hline CFOVOL & 0.7001 & 0.2323 & 0.7881 & 0.1953 \\
\hline CAPEX & $-1.3104^{* *}$ & 0.0315 & $-1.6489 * * *$ & 0.0098 \\
\hline DIV & $0.1480 * *$ & 0.0174 & $0.1414^{* *}$ & 0.0303 \\
\hline Year Dummies & Yes & & Yes & \\
\hline $\mathrm{N}$ & 2095 & & 2095 & \\
\hline ar1 (p-value) & 0.0000 & & 0.0000 & \\
\hline ar2 (p-value) & 0.3664 & & 0.3686 & \\
\hline Hansen (p-value) & 0.2321 & & 0.1965 & \\
\hline \multicolumn{5}{|c|}{$\begin{array}{l}\text { Note: This table reports the system GMM regression results of the baseline cash holdings model. } \\
\text { The estimates are robust to heteroscedastic standard errors. } N \text { indicates number of observations. } \\
\text { ar1 and ar } 2 \text { are serial correlation tests of orders } 1 \text { and } 2 \text {, respectively using residuals in first } \\
\text { differences, asymptotically distributed as } \mathrm{N}(0,1) \text { under the null of no serial correlation. Hansen is a } \\
\text { test of the overidentifying restrictions, asymptotically distributed as } \chi 2 \text { under the null of no } \\
\text { correlation between the instruments and the error term. }{ }^{*}, * *, * * * \text { denote statistical significance at } \\
10 \%, 5 \% \text { and } 1 \% \text { levels, respectively. }\end{array}$} \\
\hline
\end{tabular}

\subsection{Impact of Trade Receivables Volatility on Cash Holdings}

Table 4 presents the results of multivariate regression on the relationship between volatility of investment in trade credit and cash holdings. The model includes CASH as the dependent variable, first lag of CASH, RECVOL, controls and year dummies as explanatory variables. RECVOL is included in the model to proxy for the volatility of investment in trade receivables and is treated as an endogenous variable as discussed in Section 3.3. Model 1 and Model 2 in Table 4 present the results of the estimation where dependent variables are CASH1 and $\mathrm{CASH} 2$, respectively. As per the estimation results, RECVOL coefficients are negative and statistically significant at $5 \%$ levels in both models. The signs and significance levels of the other variables are the same as those in the baseline model, except for CFOVOL. With the inclusion of RECVOL in the model, CFOVOL coefficient has become significant at $5 \%$ levels in both models. The sign of CFOVOL is positive, which is in line with the literature supporting the rationale that firms with more volatile cash flows tend to hold more cash.

RECVOL coefficients are -4.3461 and -4.7665 in Model 1 and Model 2, respectively. This implies that as companies adopt policies that lead to higher volatility in trade receivables investment, their cash holdings are reduced. This suggests that, the increased frequency of unexpected shocks to the collection process resulting from aggressive trade receivables policies makes cash management difficult to administer. Therefore, high volatility in trade receivables hampers the ability of companies to take proactive action to prevent cash levels from getting reduced or limits the effectiveness of such proactive action. Consequently, higher volatility of trade receivables puts downward pressure on cash holdings. These findings support our hypothesis $(\mathrm{H} 1)$ that trade receivables volatility has negative impact on corporate cash holdings.

Table 4: Estimation Results - Impact of Trade Receivables Volatility on Cash Holdings

\begin{tabular}{lcccc}
\hline \multirow{2}{*}{ Variable } & \multicolumn{2}{c}{ Model 1 } & \multicolumn{2}{c}{ Model 2 } \\
& \multicolumn{1}{c}{ Dependent Variable: CASH1 } & \multicolumn{2}{c}{ Dependent Variable: CASH2 } \\
\cline { 2 - 5 } & Coefficient & p-value & Coefficient & p-value \\
\hline RECVOL & $-4.3461^{* *}$ & 0.0166 & $-4.7665^{* *}$ & 0.0111 \\
CASH $_{\mathrm{t}-1}$ & $0.3949^{* * *}$ & 0.0000 & $0.4089^{* * *}$ & 0.0000 \\
GROWTH & $0.8099^{* * *}$ & 0.0000 & $0.8960^{* * *}$ & 0.0000 \\
SIZE & $0.1064^{* * *}$ & 0.0002 & $0.1081^{* * *}$ & 0.0002 \\
LEVERAGE & $-0.0058^{* * *}$ & 0.0005 & $-0.0062^{* * *}$ & 0.0004 \\
CFO & $2.4884^{* * *}$ & 0.0000 & $2.7513^{* * *}$ & 0.0000
\end{tabular}




\begin{tabular}{lccrc} 
NWCAP & $-0.5829^{* *}$ & 0.0105 & $-0.6761^{* * *}$ & 0.0044 \\
PPE & $-1.3485^{* * *}$ & 0.0000 & $-1.4500^{* * *}$ & 0.0000 \\
CFOVOL & $1.2646^{* *}$ & 0.0421 & $1.4119^{* *}$ & 0.0289 \\
CAPEX & $-1.3662^{* *}$ & 0.0276 & $-1.7070^{* * *}$ & 0.0086 \\
DIV & $0.1580^{* *}$ & 0.0113 & $0.1530^{* *}$ & 0.0198 \\
Year Dummies & Yes & & Yes & \\
\hline $\mathrm{N}$ & 2076 & 2076 & \\
ar1 (p-value) & 0.0000 & & 0.0000 & \\
ar2 (p-value) & 0.2615 & & 0.2629 & \\
Hansen (p-value) & 0.4183 & & 0.4134 & \\
\hline
\end{tabular}

Note: This table reports the system GMM regression results of the direct impact of RECVOL on cash holdings. The estimates are robust to heteroscedastic standard errors. RECVOL is included as an endogenous variable in the dynamic panel estimation and is instrumented by lag 2 . $N$ indicates number of observations. ar 1 and ar 2 are serial correlation tests of orders 1 and 2, respectively using residuals in first differences, asymptotically distributed as $N(0,1)$ under the null of no serial correlation. Hansen is a test of the overidentifying restrictions, asymptotically distributed as $x 2$ under the null of no correlation between the instruments and the error term.

$*, * *, * * *$ denote statistical significance at $10 \%, 5 \%$ and $1 \%$ levels, respectively.

This constitutes valuable new evidence on the consequences of trade receivables on three fronts. First, no study to date (except Wu et al. (2012)) has provided evidence on the cash holdings consequences of trade credit provision. Therefore, this is the second study to document the direct impact of investment in trade receivables on cash holdings in an emerging market. Second, trade credit literature has not studied the consequences of trade receivables volatility at all. This is the first study that approaches trade receivables provision differently and utilizes volatility of investment in trade receivables, rather than the level of trade receivables, as the key variable of interest and investigate the cash holdings consequences of such policy. Therefore, we document for the first time in trade credit literature that volatility of investment in trade receivables may have performance-related and financial-policy-related consequences. Third, this study extends the findings of Uyar and Kuzey (2014) by providing further evidence on the determinants of cash holdings for Turkish listed firms. Our findings regarding the direct impact of SIZE and CFOVOL on cash holdings of listed Turkish industrials also constitute valuable evidence.

\subsection{Robustness Checks}

The model is re-tested with two additional RECVOL definitions in order to ensure the robustness of empirical findings to alternative definitions of RECVOL. The first alternative is RECVOL1, which is calculated as the standard deviation of "Trade Receivables / Total Assets" over the period from t-5 to $t$. The second alternative is RECVOL2, which is calculated as the standard deviation of "Trade Receivables / Total Assets" over the period from t-7 to t. Therefore, RECVOL1 and RECVOL2 are computed over a 6-year period and 8-year period, respectively. Initial observations for RECVOL1 and RECVOL2 are in 2005 and in 2007, respectively. The results of multivariate regression on the relationship between volatility of investment in trade credit and cash holdings using RECVOL1 and RECVOL2 as two alternative definitions of trade receivables volatility are presented in Table 5.

Consistent with the results from previous regressions, RECVOL1 and RECVOL2 coefficients continue to have negative sign and also remain statistically significant at $1 \%$ and $5 \%$ levels, respectively. The signs and significance levels of control variables remain unchanged. Therefore, the negative and significant impact of trade receivables volatility on cash holdings persists even when we use alternative definitions of RECVOL. This robustness check provides further evidence that supports our hypothesis $\mathrm{H} 1$. Therefore, our conclusions remain the same. 
Table 5: Estimation Results - Robustness of the Model to Alternative RECVOL Definitions

\begin{tabular}{|c|c|c|c|c|c|c|}
\hline \multirow{2}{*}{ Variable } & \multicolumn{3}{|c|}{$\begin{array}{c}\text { Model } 1 \\
\text { Dependent Variable: CASH1 }\end{array}$} & \multicolumn{3}{|c|}{$\begin{array}{c}\text { Model } 2 \\
\text { Dependent Variable: } \text { CASH2 }\end{array}$} \\
\hline & \multicolumn{3}{|c|}{$\begin{array}{c}\text { Coefficient } \\
\text { (p-value) }\end{array}$} & \multicolumn{3}{|c|}{$\begin{array}{c}\text { Coefficient } \\
\text { (p-value) }\end{array}$} \\
\hline RECVOL & $\begin{array}{l}-4.3461^{* *} \\
(0.0166)\end{array}$ & & & $\begin{array}{l}-4.7665^{* *} \\
(0.0111)\end{array}$ & & \\
\hline RECVOL1 & & $\begin{array}{l}5.5633^{*} \\
(0.002)\end{array}$ & & & $\begin{array}{l}9626^{*} \\
.002)\end{array}$ & \\
\hline RECVOL2 & & & $\begin{array}{l}4.9930^{* *} \\
0.044)\end{array}$ & & & $\begin{array}{l}5.3330^{* *} \\
0.037)\end{array}$ \\
\hline Controls & Yes & Yes & Yes & Yes & Yes & Yes \\
\hline Year Dummies & Yes & Yes & Yes & Yes & Yes & Yes \\
\hline $\mathrm{N}$ & 2076 & 1824 & 1528 & 2076 & 1824 & 1528 \\
\hline ar1 (p-value) & 0.0000 & 0.000 & 0.000 & 0.0000 & 0.000 & 0.000 \\
\hline ar2 (p-value) & 0.2615 & 0.154 & 0.375 & 0.2629 & 0.155 & 0.362 \\
\hline Hansen ( $p$-value) & 0.4183 & 0.475 & 0.277 & 0.4134 & 0.498 & 0.278 \\
\hline
\end{tabular}

Note: This table reports the system GMM regression results of the direct impact of RECVOL1 and RECVOL2 on cash holdings. The estimates are robust to heteroscedastic standard errors. RECVOL1 and RECVOL2 are included as endogenous variables in the dynamic panel estimation and are instrumented by their respective lag 2. Control variables and year dummies are included in the regressions. $\mathrm{N}$ indicates number of observations. ar1 and ar 2 are serial correlation tests of orders 1 and 2, respectively using residuals in first differences, asymptotically distributed as $\mathrm{N}(0,1)$ under the null of no serial correlation. Hansen is a test of the overidentifying restrictions, asymptotically distributed as $\chi 2$ under the null of no correlation between the instruments and the error term. ${ }^{*},{ }^{* *}, * * *$ denote statistical significance at $10 \%, 5 \%$ and $1 \%$ levels, respectively.

\section{CONCLUSION}

The study of whether trade receivables volatility affect corporate cash holdings has been ignored in the literature. Unlike previous studies, this study's center of interest is volatility of investment in trade receivables. Such analysis is even more critical for Turkish listed firms not only because one fourth of their assets are invested in trade receivables on average but also because they hold relatively low levels of cash compared to firms operating in other emerging countries (Fernandes \& Gonenc, 2016).

Firm's trade receivables policy constitutes an important and essential component of short-term financial policy. An inappropriate trade receivables policy may create instability in how much a firm invests in trade credit. Customer selection, credit terms offered to clients and credit monitoring process are the three most important pillars of trade receivables policy (Gitman \& Zutter, 2015). A misalignment of these pillars may lead to instability in trade receivables. This situation may further result in unfavorable consequences regarding the firm's financial position and performance. It is hypothesised that firms with relatively higher trade receivables volatility tend to have lower cash holdings mainly due to increased unpredictability surrounding the collection process. This situation hampers the ability of management to keep corporate cash levels unaffected.

This hypothesis is empirically tested for a sample of industrial firms listed on Borsa Istanbul using system GMM. Results show that, as hypothesised, firms with relatively higher RECVOL hold significantly less cash than their counterparts with low RECVOL. This result is robust to alternative definitions of cash holdings and RECVOL. By employing system GMM, we also address the potential endogeneity issue related with cash holdings and volatility of trade receivables.

This study extends trade credit literature by focusing on the stability and consistency of trade receivables policy over time. It also contributes to the literature on corporate cash holdings by identifying trade receivables volatility as an additional factor that explains a part of the variation in cash holdings. Future research may consider analyzing the affect of trade receivables volatility on cash holdings across public as well as private firms operating in other emerging and developed markets. Other 
consequences of trade receivables volatility, such as firm value and excess return, also constitute alternative areas for further research.

\section{REFERENCES}

Arellano, M., \& Bond, S. (1991). Some tests of specification for panel data: Monte Carlo evidence and an application to employment equations, The Review of Economic Studies, 58, 277-297.

Bates, T., Kahle, K., \& Stulz, R. (2009). Why do US firms hold so much more cash than they used to? Journal of Finance, 64, $1985-2021$.

Biais, B., \& Gollier, C. (1997). Trade Credit and Credit Rationing. The Review of Financial Studies, 10(4), 903-937.

Blundell, R., \& Bond, S. (1998). Initial conditions and moment restrictions in dynamic panel models. Journal of Econometrics, 87, $115-143$.

Box, T., Davis, R., Hill, M., \& Lawrey, C. (2018). Operating Performance and Aggressive Trade Credit Policies. Journal of Banking and Finance, $89,192-208$.

Brechling, F., \& Lipsey, R. (1963). Trade credit and monetary policy. The Economic Journal, 73(292), 618-641.

Brown, J., \& Petersen, B. (2011). Cash holdings and R\&D smoothing. Journal of Corporate Finance, 17, 694-709.

Burkart, M., \& Ellingsen, T. (2004). In-Kind Finance: A Theory of Trade Credit. The American Economic Review, 94(3), 569-590.

Chen, C., \& Kieschnick R. (2018). Bank credit and corporate working capital management. Journal of Corporate Finance, $48,279-596$.

Cheng, N.S. \& Pike, R. (2003). The Trade Credit Decision: Evidence of UK Firms. Managerial and Decision Economics, $24,419-438$.

Dass, N., Kale, J., \& Nanda, V. (2015). Trade credit, relationship-specific investment, and product market power. Review of Finance, 19(5), 1867-1923.

Deloof, M. (2003). Does Working capital management affect profitability of Belgian firms? Business Finance and Accounting, 30(3-4), 573587.

Deloof, M., \& Jegers, M. (1996). Trade Credit, Product Quality, and Intragroup Trade: Some European Evidence. Financial Management, 25(3), 33-43.

Dittmar, A., \& Mahrt-Smith, J. (2007). Corporate governance and the value of cash holdings. Journal of Financial Economics, 83, $599-634$.

Doring, S., Drobetz, W., Janzen, M., \& Meier, I. (2018). Global Cash Flow Sensitivities. Finance Research Letters, 25, $16-22$.

Dudley, E., \& Zhang, N. (2016). Trust and corporate cash holdings. Journal of Corporate Finance, 41, 363-387.

Duran, R., Lozano, M., \& Yaman, S. (2016). Is Family Control Relevant for Corporate Cash Holding Policy? Journal of Business Finance and Accounting, 43(9-10), 1325-1360,.

El Ghoul, S., \& Zheng, X. (2016). Trade Credit Provision and National Culture. Journal of Corporate Finance 41, 475-501.

Fernandes, N., \& Gonenc, H. (2016). Multinationals and cash holdings. Journal of Corporate Finance, 39, $139-154$.

Ferrando, A., \& Mulier, K. (2013). Do firms use the trade credit channel to manage growth. Journal of Banking and Finance, 37(8), 3035-3046.

Gao, H., Harford, J., \& Li, K. (2013). Determinants of corporate cash policy: Insights from private firms. Journal of Financial Economics, 109, 623-639.

Garcia-Teruel, P., \& Martinez-Solano, P. (2007). Effects of working capital management on the SME profitability. International Journal of Managerial Finance, 3, 164-177.

Garcia-Teruel, P., \& Martinez-Solano, P. (2008). On the determinants of SME cash holdings: Evidence from Spain. Journal of Business Finance and Accounting, 35(1-2), 127-149.

Garcia-Teruel, P., \& Martinez-Solano, P. (2010). Determinants of trade credit: A comparative study of European SMEs. International Small Business Journal 28(3) 215-233.

Ghaly, M., Dang, V., \& Stathopoulos, K. (2017). Cash Holdings and Labor Heterogeneity: The Role of Skilled Labor. The Review of Financial Studies, 30(10), 3636-3668.

Gill, A., Biger, N., \& Mathur, N. (2010). The relationship between working capital management and profitability: Evidence from the United States. Business and Economics Journal, 10, 1-9.

Gitman, L. J., \& Zutter, C.J. (2015). Principles of Managerial Finance (14th Edition) Harlow, Pearson Education Limited. 
Graham, J., \& Leary, M. (2018). The evolution of corporate cash. The Review of Financial Studies, 31(11), 4288-4344.

Guney, Y., Ozkan, A., \& Ozkan, N. (2003). Additional International Evidence on Corporate Cash Holding. Working Paper (SSRN Electronic Library).

Guney, Y., Ozkan, A., \& Ozkan, N. (2007). International evidence on the non-linear impact of leverage on corporate cash holdings. Journal of Multinational Financial Management, 17, 45-60.

Hanlon, M., Maydew, E., \& Saavedra, D. (2017). The taxman cometh: Does tax uncertainty affect corporate cash holdings? Review of Accounting Studies, 22, 1198-1228.

Hansen, L. (1982). Large sample properties of generalized method of moments estimators. Econometrica, 50, 1029-1054.

Harford, J., Mansi, S., \& Maxwell, W. (2008). Corporate governance and firm cash holdings in the US. Journal of Financial Economics, 87, 535555.

Harris, C. (2015). Trade Credit and Financial Flexibility. Banking and Finance Review, 7(1), 47-57.

Haushalter, D., Klasa, S., \& Maxwell, W. (2007). The influence of product market dynamics on a firm's cash holdings and hedging behavior. Journal of Financial Economics, 84, 797-825.

Hill, M., Kelly, G., \& Lockhart, G. (2012). Shareholder returns from supplying trade credit. Financial Management, 41, 255-280.

Hill, M., Kelly, G., \& Venkiteshwaran, V. (2015). On the Diminishing Return to Trade Credit. The Journal of Financial Research, $38(3), 305-317$. Itzkowitz, J. (2013). Customers and cash: How relationships affect suppliers' cash holdings. Journal of Corporate Finance, 19, 159-180.

Jensen, M., \& Meckling, W. (1976). Theory of the firms; Managerial behavior, agency costs and ownership structure. Journal of Financial Economics, 3(4), 305-360.

Kalcheva, \& Lins. (2007). International Evidence on Cash Holdings and Expected Managerial Agency Problems. The Review of Financial Studies, 20(4), 1087-1112.

Kim, C., Mauer, D., \& Sherman, A. (1998). The determinants of corporate liquidity: Theory and evidence. Journal of Financial and Quantitative Analysis, 33, 305-334.

Loncan, T. (2019). Foreign institutional ownership and corporate cash holdings: Evidence from emerging economies. International Review of Financial Analysis, Available online 22 December 2018 (In Press).

Long, M., Malitz, I., \& Ravid, S. (1993). Trade Credit, Quality Guarantees, and Product Marketability. Financial Management, 22(4), $117-127$.

Love, I., Preve, L., \& Sarria-Allende, V. (2007). Trade credit and bank credit: Evidence from recent financial crises. Journal of Financial Economics, 83, 453-469.

McLean, R., \& Zhao, M. (2018). Cash savings and capital markets. Journal of Empirical Finance, 47, 49-64.

Meltzer, A. (1960). Mercantile credit, monetary policy, and size of firms. The Review of Economics and Statistics, 42, $429-437$.

Melumad, N., \& Nissim, D. (2009). Line-Item Analysis of Earnings Quality. Foundations and Trends ${ }^{\circledR}$ in Accounting, 3(2-3), 87-221.

Mian, S., \& Smith, C. (1992). Accounts receivable management policy: theory and evidence. The Journal of Finance, 47(1), 169-200.

Miller, M., \& Orr, D. (1966). A model of the demand for money by firms. Quarterly Journal of Economics, 80, 413-435.

Myers, S. (1984). The capital structure puzzle. Journal of Finance, 39, 575-592.

Myers, S., \& Majluf, N. (1984). Corporate financing and investment decisions when firms have information that investors do not have. Journal of Financial Economics, 13, 187-221.

Opler, T., Pinkowitz, L., Stulz, R., \& Williamson, R. (1999). The determinants and implications of corporate cash holdings. Journal of Financial Economics, 52, 3-46.

Ozkan, A., \& Ozkan, N. (2004). Corporate cash holdings: an empirical investigation of UK companies. Journal of Banking and Finance, 28, 2103-2134.

Paul, S. (2004). Strategic trade credit: an empirical study, PhD thesis. Leeds: Leeds University Business School.

Petersen, M., \& Rajan, R. (1994). The Benefits of Lending Relationships: Evidence from Small Business Data. Journal of Finance, 43 , 9-26.

Petersen, M., \& Rajan, R. (1997). Trade credit: theories and evidence. Review of Financial Studies, 10(3), 661-691.

Pinkowitz, L., Stulz, R., \& Williamson, R. (2003). Do firms in countries with poor protection of investor rights hold more cash? Cambridge: NBER Working Paper 10188. 
Roodman, D. (2009). How to do xtabond2: an introduction to difference and system GMM in Stata. Stata Journal, 9, 86-136.

Subramaniam, V., Tang, T., Yue, H., \& Zhou, X. (2011). Firm structure and corporate cash holdings. Journal of Corporate Finance, 17(3), 759771.

Uyar, A., \& Kuzey, C. (2014). Determinants of corporate cash holdings: evidence from the emerging market of Turkey. Applied Economics, 46(9), 1035-1104.

Wilson, N. \& Summers, B. (2002). Trade credit terms offered by small firms: Survey evidence and ampirical analysis. Journal of Business Finance and Accounting, 29 (3-4), 317-351.

Wu, W., Rui, O., \& Wu, C. (2012). Trade credit, cash holdings, and financial deepening: Evidence from a transitional economy. Journal of Banking and Finance, 36, 2868-2883.

Yazdanfer, D., \& Ohman, P. (2015). The impact of credit supply on sales growth: Swedish evidence. International Journal of Managerial Finance, 11(3), 329-340. 